トピックス 新進気鋭 シリーズ
第50回 日本生物物理学会年会 若手招待講演

\section{脂質膜へテロ界面はナノ物質をサイズ依存的に 識別する}

演田 勉 北陸先端科学技術大学院大学マテリアルサイエンス研究科

\section{1. はじめに}

近年，医療や化粧品など多くの産業分野で，新たな 機能性材料としてナノ粒子の研究開発が進んでいる. しかし，ナノサイズの物質の生体や人体に対する影響 はよくわかっておらず，その客観的な評価基準の確立 が急がれている ${ }^{1)}$. 生体に対する作用機構を理解する ためには，生体を構成する細胞の表面，すなわち細胞膜 でのナノ粒子の振る舞いを明らかにすることが必須と なる（図 1)。本稿では，生細胞膜の特徵的構造を再現 した人工細胞膜（細胞サイズリポソーム）を用いた ${ }^{2)}$, 脂質膜とナノ粒子との相互作用の研究成果を紹介する.

\section{2. 相分離により形成される細胞表面のへテロ構造}

細胞膜は，多成分の脂質から成る分子集合体であ る。膜を構成する脂質分子は，膜面で一様に混合せ ず，周囲から分離した領域（膜ドメイン，たとえば脂 質ラフト）を形成している (図 1 ${ }^{3}$ )。 この膜ドメイン は受容体タンパク質等を選択的に局在させ，シグナル 伝達や小胞輸送などの場として機能すると考えられて いる．膜ドメインの形成原理は，膜内の相分離現象と して理解できる．相転移温度の異なる脂質分子が共存 すると，脂質分子のアシル基の運動性が抑えられた 「秩序相」状態（膜ドメインに対応する）と，流動性 の高い「無秩序相」状態の領域（周囲の膜に対応する） に，それぞれの分子が分布する.

このような細胞膜のへテロ界面は，人工脂質膜小胞 (リポソーム) で再現することができる ${ }^{4)}$ 。コレステ ロール・飽和脂質・不飽和脂質から細胞サイズのリポ ソームを作製し，流動性の高い非ドメイン領域に局在 する蛍光色素を用いることで，リポソーム表面のドメ イン構造を可視化する.

\section{3. 脂質膜へテロ界面へのナノ粒子の吸着挙動}

我々は，このへテロ界面を持つ細胞サイズリポソー ムに対して，直径 50 ～ $1000 \mathrm{~nm}$ のポリスチレン粒子
を添加し，相互作用を蛍光顕微鏡で観察した ${ }^{5)}$ 。する と, 粒子サイズ $200 \mathrm{~nm}$ を境に，小さい粒子はドメイ ンに，大きい粒子は周囲の非ドメイン領域に選択的に 吸着した（図 2)。また，温度変化による一時的なド メイン消滅や，レーザートラップによる外力印加など の摇動に対して，ナノ粒子はこの局在性を維持した. 生細胞膜において膜ドメインはエンドサイトーシス小 胞を形成する場として考えられており，このドメイン 誘起エンドサイトーシスは人工膜で再現されてい る ${ }^{6}$ 。 すなわち，我々の実験結果は，小さいナノ粒子 はドメインを介して細胞内に取り込まれやすい事を示 唆している.

4. ナノ粒子吸着に伴う脂質膜の自由エネルギー変化

次に，ナノ粒子が示す膜局在の物理メカニズムにつ いて考察する。本実験条件では，粒子と膜の間に㗢く 主な力はvan der Waals 引力であり，粒子は膜に吸着す る。このとき，吸着力が大きければ，接触面積を増や すため膜は粒子を覆うよらに変形する。しかし，膜が 変形するには，膜の弾性力に打ち勝つ必要がある。こ の 2 つの競合する力 (エネルギ一) を比較すると，膜 変形を誘起する臨界粒子サイズ $\mathrm{D}=2(2 \kappa / \mathrm{w})^{1 / 2}$ が求ま る。ここで，wは膜と粒子の吸着エネルギ一， ผは膜の 弾性係数を表す。こに，典型的な物性值を代入する と，粒子の直径 D が $260 \mathrm{~nm}$ と求まる。この值は，実 験で観察された膜ドメインに局在する粒子サイズの閾 值（200 nm）とほぼ同じであり，膜変形の有無が粒 子の局在メカニズムに関わっていることを示している.

臨界サイズ以上の粒子は，吸着エネルギーの寄与が 大きく，膜は粒子を覆らように変形する．膜が変形す る場合，系の自由エネルギーは曲率弾性エネルギーで 記述でき，そのエネルギーは弾性係数に比例する。す なわち，弾性係数の小さい周囲の非ドメイン領域への 粒子の局在が安定となる。一方，臨界サイズ以下の粒 子は，弾性エネルギーの寄与が大きく，膜の曲率変形 は起こりにくい。しかし，粒子の吸着に伴い膜の熱摇

Size-dependent Partitioning of Nanoparticles Mediated by Membrane Lateral Heterogeneity

Tsutomu HAMADA

School of Materials Science, Japan Advanced Institute of Science and Technology 


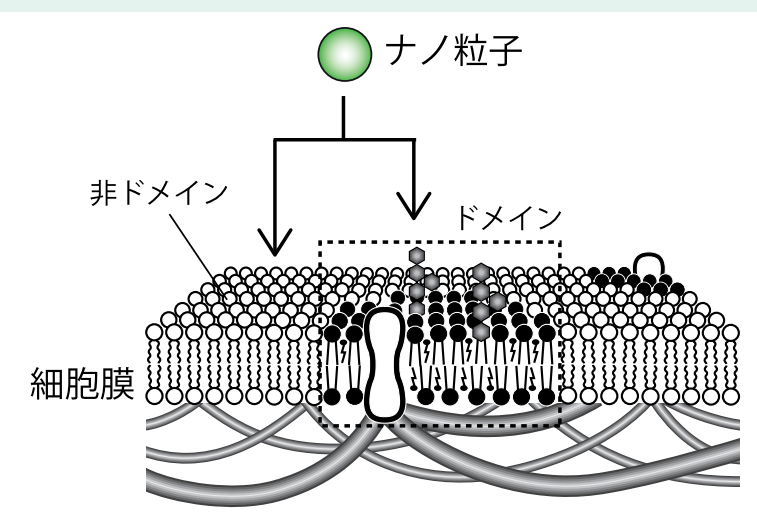

図 1

細胞膜へのナノ粒子の作用.

(a) $100 \mathrm{~nm}$ ナノ粒子
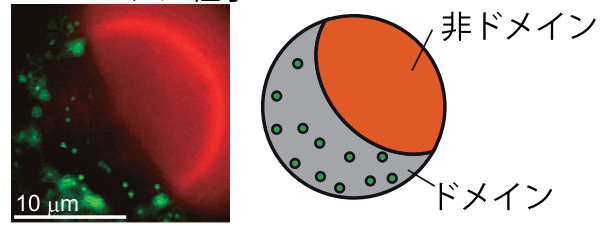

(b) $500 \mathrm{~nm}$ ナノ粒子

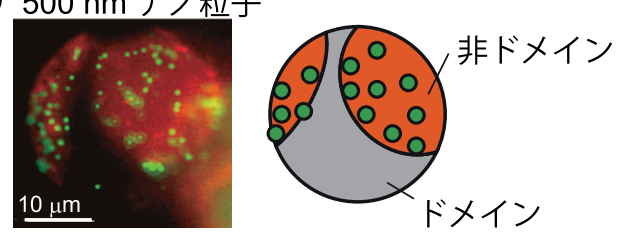

(c) 小さいナノ粒子 大きいナノ粒子

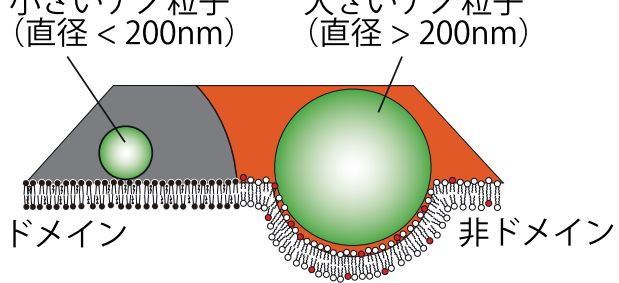

図 2

細胞サイズリポソームへのナノ粒子の吸着挙動. 蛍光顕微鏡像 （a，b）と模式図（c). 緑色がナノ粒子，赤色が非ドメイン領域 （無秩序相）に分布する蛍光脂質に由来する. (Reprinted with permission from J. Am. Chem. Soc., 134, 13990-13996 (2012). Copyright 2012 American Chemical Society.)

らぎが制限されるため，エントロピーが減少する。こ の自由エネルギー変化は, 弾性係数に反比例するた め, 元々摇らぎが少ない低流動性の膜ドメインに吸着 する方が安定である。このように，膜の自由エネル ギーにより，サイズ依存的な粒子の分配挙動を定性的 に説明することができる.

\section{5. まとめと展望}

本稿では，人工細胞膜を用いたナノ粒子の挙動解析 を紹介した，ナノ粒子が膜表面に吸着する様子は，粒 子の大きさに依存して変化する，すなわち，小さい粒 子ほぞ膜ドメインに局在しやすいことを見出した。そ して，その物理メカニズムは，粒子吸着に伴う膜の自 由エネルギー変化により理解することができる，これ は，脂質膜の物性が，膜表面上でナノ粒子を分配する 機能を備えていることを意味する，また，ナノ粒子に 加えて, 我々は, 自己会合性のペプチド（アミロイド $\beta$ ペプチド）が，その重合度（分子の大きさ）に応じ て，膜ドメインへの局在状態を変化させることも発見 している ${ }^{7}$. この様に, 脂質膜のへテロ界面は, 様々 な物質分子に対して，根源的な「識別」機能を果たし ていることが予想される。 また，細胞内には小胞体等 の脂質膜で作られたコンパートメントがいたる所に存 在しており, これらの膜界面もへテロ構造であること が示唆されている ${ }^{8)}$. 寸なわち，細胞内部における分 子反応の制御にも，へテロ膜界面が寄与している可能 性が大きい.

本稿で紹介した研究成果の共同研究者である北陸先 端科学技術大学院大学の高木昌宏教授に感謝いたしま す。本研究は，科学研究費補助金の支援を受けて行わ れました。

文 献

1) Nel, A. et al. (2006) Science 311, 622-627.

2) Hamada, T., Yoshikawa, K. (2012) Materials 5, 2292-2305.

3) Simons, K., Gerl, M. J. (2010) Nat. Rev. Mol. Cell Biol. 11, 688699.

4) Hamada, T. et al. (2011) Soft Matter 7, 9061-9068.

5) Hamada, T. et al. (2012) J. Am. Chem. Soc. 134, 13990-13996.

6) Hamada, T. et al. (2007) J. Phys. Chem. B 111, 10853-10857.

7) Morita, M. et al. (2012) Soft Matter 8, 2816-2819.

8) van Meer, G. et al. (2008) Nat. Rev. Mol. Cell Biol. 9, 112-124.

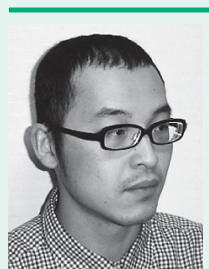

湄田 勉（はまだ つとむ）

北陸先端科学技術大学院大学マテリアルサイエン 又研究科准教授

2006 年京大理学研究科博士課程修了. 博士（理 学). 北陸先端大助教を経て 11 年より現職. 研究内容:ソフトマター物理学に基づく人工細胞 設計

演田勉連絡先: $=923-1292$ 石川県能美市旭台 1-1

E-mail: t-hamada@jaist.ac.jp

URL: http://www.jaist.ac.jp/ms/labs/hamada/ 